\title{
Faktor yang Mempengaruhi Pengetahuan Ibu tentang Makanan Pendamping Air Susu Ibu
}

\section{Factor that affect mother's knowledge of the food escort mother's breast milk}

\author{
Dita Kristiana $^{1 *}$, Sri Subiyatun Widaningsih ${ }^{2}$ \\ 1,2Universitas 'Aisyiyah Yogyakarta, Jl RingRoad Barat, Nogotirto, Gamping, Sleman, \\ Yogyakarta, Indonesia \\ 1'ditakristiana@unisayogya.ac.id *; ${ }^{2}$ srisubiyatun@gmail.com \\ * corresponding author \\ Tanggal Submisi: 8 Oktober 2021 , Tanggal Penerimaan: 5 November 2021
}

\begin{abstract}
Abstrak
Makanan pendamping ASI adalah makanan minuman yang diberikan bersama dengan pemberian Air Susu Ibu sampai 2 tahun. Penelitian mempunyai tujuan untuk mengetahui faktor yang mempengaruhi pengetahuan ibu tentang makanan pendamping air susu ibu. Desain penelitian ini cross sectional. Metode pengambilan sampel accidental sampling menggunakan kuisioner, sampel 38 orang. Faktor yang mempengaruhi pengetahuan antara lain umur, pendidikan, informasi atau media massa, sosial budaya dan ekonomi, lingkungan, pengalaman. Analisis data univariat dan multivariat. Hasilnya dari $38 \mathrm{ibu}$, pengetahuan cukup 26 orang $(68.42 \%)$, yang mempunyai umur $20-35$ tahun 28 orang $(73.7 \%)$, multipara 10 orang $(26.3 \%)$, primipara 10 orang $(26.3 \%)$, pendidikan SMA 22 orang (57.89), tidak bekerja 29 orang $(76.32 \%)$. Pendapatan paling banyak Rp 500.000,00-Rp 1.000 .000 ada 17 orang (44.7\%). Sumber informasi dari Puskesmas 25 orang (65.8\%).Saran meningkatkan KIE ibu hamil maupun yang punya batita.
\end{abstract}

Kata kunci: Faktor; pengetahuan ibu; MP-ASI

\begin{abstract}
MP ASI is food and drink given at the same time as breastfeeding for up to 2 years. This study aims to determine the factors that influence mother's knowledge about MP ASI. The research design was cross sectional, accidental sampling with questionnaires, a sample of 38 people. Factors that influence knowledge include education, information or mass media, social, culture and economy, environment, experience. Univariate data analysis. The result is that from 38 mothers, 26 people (68.42\%), who are 20-35 years old have enough knowledge, 28 people (73.7\%), 10 multiparas (26.3\%), 10 primiparas (26.3\%), high school education 22 people (57.89 ), not working 29 people (76.32\%). There are 17 people (44.7\%). Sources of information from the Puskesmas were 25 people (65.8\%), suggestions for increasing IEC for pregnant women and those with toddlers.
\end{abstract}

\section{PENDAHULUAN}

Pangan adalah segala sesuatu yang berasal dari sumber hayati dan air, yang diolah maupun tidak, yang diperuntukkan sebagai makanan atau minuman bagi konsumsi manusia (Tria et al., 2018). Masalah gizi kurang pada bayi dapat terjadi setelah bayi berumur di atas 6 bulan akibat air susu ibu (ASI) yang diberikan tidak

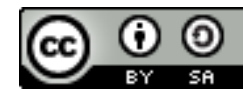


lagi mencukupi kebutuhan fisiologi bayi untuk tumbuh dan berkembang (Siolimbona et al., 2016). Makanan yang mengandung gizi yang lengkap dan seimbang, dari segi kuantitas dan kualitas sangat dibutuhkan untuk pertumbuhan dan perkembangan yang optimal, serta memelihara daya tahan tubuh dari berbagai infeksi, sehingga dapat membangun persediaan zat gizi yang dibutuhkan untuk proses tumbuh di masa pubertas dan dewasa kelak (MATTOS, 2011). Bayi dan balita masuk dalam kelompok rawan gizi di masyarakat dimana prevalensi gizi kurang tertinggi pada bayi dan balita (Aprillia et al., 2019). Pertumbuhan bayi dapat terhambat apabila hanya diberi ASI (ASI) saja tanpa mendapat Makanan Pendamping Air Susu Ibu (MP ASI) setelah berusia 6 bulan, karena tidak terpenuhinya zat gizi untuk pertumbuhan dan perkembangan (Widyaningtyas, 2015). Dalam setiap langkah dan perkembangan dalam hidup si kecil, mama pasti ingin memberikan yang terbaik. Salah satu momen terpenting adalah saat ia mulai makan makanan pendamping ASI (Zahrial, et all. 2015).

Proses menyusui dilakukan segera setelah bayi lahir, bayi ditengkurepkan di dada sang ibu sehingga kulit ibu melekat pada kulit bayi selama minimal satu jam setelah lahir, atau dikenal dengan inisiasi menyusu dini (IMD). Dilanjutkan dengan pemberian Air Susu Ibu (ASI) eksklusif selama 6 bulan kehidupan bayi, pemberian MP ASI, lalu melanjutkan proses menyusui sampai usia 2 tahun atau lebih (Wandini et al., 2021). Nutrisi yang baik selama periode 1000 hari antara awal kehamilan sampai ulang tahun kedua anak sangat penting untuk masa depan kesehatan, kesejahteraan dan kesuksesan anak. Setahun pertama kehidupan anak memang merupakan masa dimana ia menjalani berbagai aspek tumbuh kembang amat pesat (Nengsih et al., 2020). Rentang usia 1-2 tahun merupakan masa kritis bagi anak, karena pada usia ini terjadi pertumbuhan dan perkembangan yang sangat cepat, bahkan pertumbuhan otak pun selesai pada sekitar usia ini (18 bulan). Anak sudah tidak bisa mengandalkan air susu ibu, yang kaya dan lengkap akan zat gizi, sehingga mereka harus diberi makanan tambahan atau makanan pendamping air susu ibu (Nurlinda, 2013).

MP ASI merupakan singkatan dari makanan pendamping ASI yaitu makanan tambahan yang diberikan pada bayi selain air susu ibu ketika ASI tidak dapat mencukupi kebutuhan nutrisi anak untuk tumbuh kembang optimal (Birth, 2020). Makanan pendamping air susu ibu adalah makanan yang diberikan bersamaan dengan pemberian air susu ibu sampai dengan anak berusia 2 tahun (IBI/IMA \& IMAP, 2018). Pemberian makanan pendamping ASI yaitu pemberian makanan atau minuman yang mengandung gizi yang diberikan pada bayi atau anak yang berumur 6-24 bulan untuk memenuhi kebutuhan gizinya (Bayar, 2018). Sebanyak $71.5 \%$ anak yang mengalami kurang gizi tidak mendapatkan asupan makanan pendamping air susu ibu yang adekuat (Septikasari, 2016). Banyak orangtua beranggapan bayinya mungkin sudah siap makan sebelum usia 6 bulan (Utami, 2018). Pemberian makanan pendamping air susu ibu juga harus memperhatikan kebutuhan nutrisi anak. Makanan pendamping air susu ibu harus mencakup semua zat gizi yang dibutuhkan antara lain karbohidrat, protein, lemak, vitamin, mineral dan air dengan memperhatikan kebersihan dan keamanannya bagi bayi (da Cunha et al., 2015).

Bahan makanan MP ASI harus mengandung jenis makanan pokok (beras, jagung, singkong, ubi jalar, sagu, talas, kentang, dan lain-lain), kacang-kacangan (kacang tanah, kacang hijau, kedelai, kacang merah, dan sebagainya), sayuran 
berwarna (wortel, tomat, bayam, dan lain-lain), buah-buahan (pepaya, pisang, jeruk manis, dan lain-lain) serta lemak dan minyak (minyak, santan dan lain-lain) (Kemenkes RI, 2011). Makanan tambahan untuk bayi sebaiknya memenuhi persyaratan nilai energi dan kandungan proteinnya tinggi, memiliki nilai suplementasi yang baik, mengandung vitamin dan mineral dengan jumlah cukup, dapat diterima dengan baik, harganya relatif murah, sebaiknya dapat diproduksi dari bahan-bahan yang tersedia secara lokal (Adriani, dkk. 2016). Bukti kesuksesan memberikan air susu ibu dan makanan pendamping air susu ibu bergizi dengan porsi mencukupi pada bayi tercermin dari hasil pengukuran berat badan, panjang badan, dan lingkar kepala bayi menunjukkan perkembangan tempurung kepala dan otaknya (Apriadji, 2015).

Pertumbuhan bayi cepat antara usia 6 bulan sampai 1 tahun. Hal ini berpengaruh pada pola pemberian makan. Selain memenuhi kebutuhan makannya yang meningkat, memperkenalkan bayi dengan makanan padat juga membantu mengembangkan dan melatih ketrampilan makan seperti menggigit dan mengunyah.

Pemberian makanan pendamping ASI (MP ASI) menjadi satu hal yang penting dilakukan untuk meningkatkan angka kecukupan gizi dan pencegahan stunting (apriyanti widyasari, 2018). Pengetahuan ibu sangat berperan dalam periode pemberian MP ASI, sebab pengetahuan yang baik terhadap pemberian MP air susu ibu akan menyebabkan seseorang mampu menyusun menu yang baik untuk dikonsumsi oleh bayinya. Semakin baik pengetahuan gizi seseorang maka ia akan semakin memperhitungkan jenis dan jumlah makanan yang diperolehnya untuk dikonsumsi. Pada keluarga dengan pengetahuan tentang makanan pendamping air susu ibu yang rendah seringkali anaknya harus puas dengan makanan seadanya yang tidak memenuhi kebutuhan gizi balita karena ketidaktahuan. Ibu-ibu mengira bahwa selagi masih menyusu, bayinya pasti memperoleh makanan yang cukup. Kesalahan inilah yang merupakan terjadinya gizi buruk pada anak. Tujuan penelitian untuk mengetahui faktor yang mempengaruhi pengetahuan ibu tentang MP ASI.

\section{METODE}

Penelitian ini merupakan penelitian dengan metode survei analitik dengan pendekatan potong lintang (cross sectional). Penelitian cross sectional sering disebut penelitian transversal, untuk mempelajari dinamika korelasi antara faktor risiko dengan efek, dengan cara pendekatan, observasi, atau pengumpulan data sekaligus pada suatu saat (point time approach). Maksudnya setiap subyek penelitian hanya diobservasi sekali dan pengukuran dilakukan tiap terhadap status karakter atau variabel subyek pada saat pemeriksaan. Hal ini tidak berarti bahwa semua subyek penelitian diamati pada waktu sama. Tempat penelitian di Margomulyo Seyegan Sleman Yogyakarta dengan jumlah populasi 38 orang. Populasi adalah ibu yang mempunyai anak usia 0-24 bulan. Waktu pelaksanaan penelitian pada bulan September 2019. Teknik sampling adalah total sampling sehingga jumlah sampel adalah 38 orang. Dalam penelitian ini kriteria inklusinya adalah ibu yang mempunyai anak umur 0-24 bulan dan ibu yang bersedia menjadi responden. Variabel dalam penelitian ini terdiri dari variabel bebas yaitu karakteristik ibu yang terdiri dari variabel umur, paritas, pendidikan, pekerjaan, sosial ekonomi dan sumber informasi. Variabel terikat adalah pengetahuan ibu 
tentang makanan pendamping ASI pada anak usia 0-24 bulan. Instrumen pengambilan data menggunakan kuisioner. Kuisioner menanyakan tentang faktor yang mempengaruhi pengetahuan ibu tentang pemberian makanan pendaming asi. Ada 2 macam validitas yaitu eksternal dan internal. Validitas eksternal instrument dicapai bila data yang dihasilkan sesuai dengan data atau informasi lain yang mengenai variable penelitian yang dimaksud. Validitas internal dicapai apabila terdapat kesesuaian antar bagian-bagian instrument dengan instrument secara keseluruhan. Data yang diperoleh kemuadian dimasukkan ke dalam tabel distribusi frekuensi dan setiap butir pertanyaan dikorelasikan dengan skor total menggunakan rumus korelasi product moment. Angka hasil perhitungan kemudian dibandingkan dengan nilai $r$ Product Moment dengan taraf signifikan 5\%. Apabila $r$ hitung $>\mathrm{r}$ table yaitu lebih besar dari 0.05 maka pernyataan dinyatakan valid. Pada penelitian ini menggunakan pengujian reliabilitas internal karena uji reliabilitas tersebut dilakukan dengan cara mencobakan instrument sekali saja, kemudian yang diperoleh dianalisis dengan tekhnik tertentu. Pengujian reliabilitas instrument dilakukan dengan tekhnik KR 20. Analisis data menggunakan analisis univariat untuk mendeskripsikan setiap variabel dan analisis multivariat untuk mengetahui hubungan antara variabel bebas dengan variabel terikat.

\section{HASIL DAN PEMBAHASAN}

\section{A. HASIL PENELITIAN}

\section{Gambaran Umum Lokasi Penelitian}

Pengambilan data dilakukan di Posyandu Nangka Gerjen, Posyandu Ngemplak Sari, dan Posyandu Gondangan. Pelaksanaan penelitian di Posyandu Nangka Gerjen pada hari Sabtu, 7 September 2019 jam 9-11.30, Posyandu Ngemplak Sari pada hari Sabtu, 7 September 2019 jam 10, Posyandu Gondangan Kamis, 18 September 2018 jam10. Jumlah kader di Posyandu Nangka Gerjen ada 8. Ketika penelitian, 1 orang kader izin. Jumlah kader Posyandu Ngemplak sari ada 5, tatapi yang aktif 4. Jumlah kader di Posyandu Gondangan 10, tetapi ketika penelitian 2 kader sedang pelatihan UKBM di Puskesmas Seyegan.

Pada saat kunjungan, setelah diberikan penjelasan dan setuju untuk menjadi responden, responden mengisi kuisioner. Jumlah balita usia 0-24 di Posyandu Nangka Gerjen ada 36 anak, tetapi yang hadir ada 11 anak, Posyandu Ngemplak Sari ada 11 orang, Posyandu Gondangan ada 16 orang. Responden di Posyandu Nangka Gerjen berasal dari 2 dusun yaitu Dukuh dan Gerjen (Autoridad Nacional del Servicio Civil, 2021). 


\section{Analisa univariat}

Pengetahuan ibu tentang makanan pendamping ASI

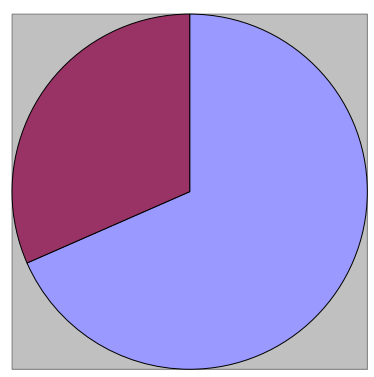

$$
\begin{gathered}
\square \text { cukup } 26 \\
(68.42 \%) \\
\square \text { baik } 12 \\
(31.58 \%)
\end{gathered}
$$

Gambar 1. Pengetahuan ibu tentang makanan pendamping ASI di Margomulyo, Seyegan,

Sleman, Yogyakarta 2019

Gambar 1 menunjukkan sebagian besar responden mempunyai pengetahuan cukup yaitu 26 responden $68,42 \%$.

\section{Karakteristik Responden}

Karakteristik responden yang dapat diperoleh dari data meliputi umur, paritas, pendidikan, dan pekerjaan.

a. Karakteristik Responden Berdasarkan Umur di Margomulyo Seyegan Sleman Yogyakarta 2019

Berdasarkan hasil penelitian, dapat dideskripsikan umur responden dalam tabel sebagai berikut :

Tabel 1. Umur Responden di Margomulyo Seyegan Sleman Yogyakarta Tahun 2019

\begin{tabular}{c|c|c} 
Umur & Frekuensi & Persen \\
\hline$<20$ tahun & 1 & 2.6 \\
\hline $20-35$ tahun & 28 & 73.7 \\
\hline$>35$ tahun & 9 & 23.7 \\
\hline Total & 38 & 100
\end{tabular}

Tabel 1 menunjukkan bahwa responden paling banyak berusia 20-35 tahun yaitu 28 orang $(73.7 \%)$ dan paling sedikit responden berusia kurang dari 20 tahun yaitu 1 orang $(2,6 \%)$.

b. Karakteristik Responden Berdasarkan Paritas di Margomulyo Seyegan Sleman Yogyakarta 2019

Tabel 2. Paritas Responden di Margomulyo, Seyegan, Sleman, Yogyakarta

\begin{tabular}{c|c|c} 
Paritas & Frekuensi & Persen \\
\hline Primipara & 10 & 26.3 \\
\hline Multipara & 28 & 73.7 \\
\hline Total & 38 & 100
\end{tabular}

Dita Kristiana, Sri Subiyatun Widaningsih (Faktor yang mempengaruhi pengetahuan ibu....) 
Tabel 2 menunjukkan responden paling banyak multipara ada 28 orang $(73.7 \%)$.

c. Karakteristik Responden Berdasarkan Pendidikan di Margomulyo Seyegan Sleman Yogyakarta 2019

Tabel 3. Karakteristik Responden Berdasarkan Pendidikan di Margomulyo, Seyegan, Sleman, Yogyakarta 2019

\begin{tabular}{c|c|c} 
Pendidikan & Frekuensi & Persen \\
\hline SD & 3 & 7.9 \\
\hline SMP & 9 & 23.7 \\
\hline SMA & 22 & 57.9 \\
\hline PT & 4 & 10.5 \\
\hline Total & 38 & 100
\end{tabular}

Berdasarkan hasil analisa data bahwa sebagian besar responden berpendidikan SMA 22 orang $57.89 \%$

d. Karakteristik Responden Berdasarkan Pekerjaan di Margomulyo Seyegan Sleman Yogyakarta 2019

Tabel 4. Karakteristik Responden Berdasarkan Pekerjaan di Margomulyo Seyegan Sleman Yogyakarta 2019

\begin{tabular}{c|c|c} 
Pekerjaan & Frekuensi & Persen \\
\hline IRT & 29 & 76.3 \\
\hline Pegawai swasta & 6 & 15.8 \\
\hline Buruh & 2 & 5.3 \\
\hline Karyawan & 1 & 2.6 \\
\hline Total & 38 & 100
\end{tabular}

Tabel 4 menunjukkan bahwa pekerjaan responden yang paling banyak adalah ibu rumah tangga yaitu sebanyak 29 orang (76,32 \%), dan yang paling sedikit responden dengan pekerjaan karyawan yaitu 1 responden $(2,63 \%)$.

e. Karakteristik Responden Berdasarkan Sosial Ekonomi di Margomulyo Seyegan Sleman Yogyakarta 2019

Tabel 5. Karakteristik Responden Berdasarkan Sosial Ekonomi Ibu di Margomulyo Seyegan Sleman Yogyakarta 2019

\begin{tabular}{c|c|c} 
Sosial ekonomi & Frekuensi & Persen \\
\hline$<500.000$ & 7 & 18.4 \\
\hline $500.000-1.000 .000$ & 17 & 44.7 \\
\hline$>1.000 .00014$ & 36.8 & $>1.000 .00014$ \\
\hline Total & 38 & 100
\end{tabular}


Berdasarkan hasil analisa didapatkan bahwa pendapatan responden paling banyak 500000-1000000 ada 17 orang (44.7\%).

f. Karakteristik Responden Berdasarkan Sumber Informasi di Margomulyo Seyegan Sleman Yogyakarta 2019

Tabel 6. Karakteristik Responden Berdasarkan Sumber Informasi di Margomulyo, Seyegan, Sleman, Yogyakarta, 2019

\begin{tabular}{c|c|c} 
Sumber informasi & Frekuensi & Persen \\
\hline Puskesmas & 25 & 65.8 \\
\hline Internet & 6 & 15.8 \\
\hline Poster & 2 & 5.3 \\
\hline Televisi & 2 & 5.3 \\
\hline Radio & 1 & 2.6 \\
\hline Buku & 1 & 2.6 \\
\hline Belum mendapatkan & 1 & 2.6 \\
\hline Total & 38 & 100
\end{tabular}

Berdasarkan hasil analisa data didapatkan bahwa bu yang mendapatkan sumber informasi melalui Puskesmas 25 orang 65.8\%.

\section{Analisa Bivariat}

a. Hubungan Umur Dengan Pengetahuan Ibu Dalam Pemberian MP ASI

Tabel 7. Hubungan Antara Umur Dengan Pengetahuan Ibu Dalam Pemberian MP ASI di Margomulyo, Seyegan, Sleman, Yogyakarta 2019

\begin{tabular}{|c|c|c|c|c|c|}
\hline \multirow[t]{2}{*}{ Umur } & \multicolumn{4}{|c|}{ Tingkat pengetahuan } & \multirow[t]{2}{*}{$\mathbf{P}$} \\
\hline & Cukup & $\%$ & Baik & $\%$ & \\
\hline$<20$ tahun & 1 & 2.6 & 0 & 0 & 0.119 \\
\hline 20-35 tahun & 15 & 39.5 & 13 & 34.2 & \\
\hline$>35$ tahun & & 8 & 21.1 & 1 & \\
\hline
\end{tabular}

Hasil penelitian menunjukkan bahwa umur ibu kurang dari 20 tahun tidak ada yang pengetahuannya baik. Ibu yang berpengetahuan cukup pada umur 21-35 tahun ada 15 responden $(39.47 \%)$.

Hasil uji statistik diperoleh p value 0.119 pada derajat kemaknaan 5\% maka dapat disimpulkan tidak ada hubungan yang bermakna antara umur dengan pengetahuan ibu dalam pemberian MP ASI.

b. Hubungan Paritas Dengan Pengetahuan Ibu

Tabel 8. Hubungan Paritas Dengan Pengetahuan Ibu Dalam Pemberian MP ASI di Margomulyo, Seyegan, Sleman, Yogyakarta 2019

\begin{tabular}{|c|c|c|c|c|c|c|c|}
\hline Paritas & \multicolumn{4}{|c|}{ Tingkat pengetahuan } & Total & $\%$ & $\mathbf{P}$ \\
\hline & Cukup & $\%$ & Baik & $\%$ & & & \\
\hline Primipara & 5 & 13.2 & 5 & 13.2 & 10 & 26.3 & 0.119 \\
\hline Multipara & 24 & 63.2 & 14 & 36.8 & 38 & 100 & \\
\hline
\end{tabular}


Hasil penelitian menunjukkan bahwa paritas ibu mutipara mempunyai pengetahuan cukup ada 19 responden (50\%).

Hasil uji statistik diperoleh p value 0.119 pada derajat kemaknaan 5\% maka dapat disimpulkan tidak ada hubungan yang bermakna antara paritas dengan pengetahuan ibu dalam pemberian MP ASI.

c. Hubungan Pendidikan Dengan Pengetahuan Ibu

Tabel 9. Hubungan Pendidikan Dengan Pengetahuan Ibu di Margomulyo, Seyegan, Sleman, Yogyakarta, 2019

\begin{tabular}{|c|c|c|c|c|c|c|c|}
\hline Pendidikan & \multicolumn{4}{|c|}{ Tingkat pengetahuan } & Total & $\%$ & $\mathbf{P}$ \\
\hline & Cukup & $\%$ & Baik & $\%$ & & & \\
\hline SD & 2 & 5.3 & 1 & 2.6 & 3 & 7.9 & 0.216 \\
\hline SMP & 8 & 21.1 & 1 & 2.6 & 7.9 & 23.7 & \\
\hline SMA & 11 & 28.9 & 11 & 28.9 & 22 & 57.9 & \\
\hline PT & 3 & 7.9 & 1 & 2.6 & 4 & 10.5 & \\
\hline Total & 24 & 63.2 & 14 & 36.8 & 38 & 100 & \\
\hline
\end{tabular}

Hasil penelitian menunjukkan bahwa ibu yang berpendidikan SMA mempunyai pengetahuan cukup ada 12 orang $(31.57 \%)$. Ibu yang berpendidikan $\mathrm{SD}$, akademi dan sarjana yang berpengetahuan baik tidak ada.

Hasil uji statistik diperoleh p value 0.216 pada derajat kemaknaan 5\% maka dapat disimpulkan tidak ada hubungan yang bermakna antara pendidikan dengan pengetahuan ibu dalam pemberian MP ASI.

d. Hubungan Pekerjaan Dengan Pengetahuan Ibu

Tabel 10. Hubungan Pekerjaan Dengan Pengetahuan Ibu di Margomulyo, Seyegan, Sleman, Yogyakarta 2019

\begin{tabular}{|c|c|c|c|c|c|c|c|}
\hline Pekerjaan & \multicolumn{4}{|c|}{ Tingkat pengetahuan } & Total & $\%$ & $\mathbf{P}$ \\
\hline & Cukup & $\%$ & Baik & $\%$ & & & \\
\hline IRT & 19 & 50 & 10 & 26.3 & 29 & 76.3 & 0.742 \\
\hline $\begin{array}{c}\text { Pegawai } \\
\text { swasta }\end{array}$ & 3 & 7.9 & 3 & 7.9 & 6 & 15.8 & \\
\hline Buruh & 1 & 2.6 & 1 & 2.6 & 2 & 5.3 & \\
\hline Karyawan & 1 & 2.6 & 1 & 2.6 & 2 & 5.3 & \\
\hline Total & 24 & 63.2 & 14 & 36.8 & 38 & 100 & \\
\hline
\end{tabular}

Hasil penelitian menunjukkan bahwa pekerjaan responden karyawan yang berpengetahuan baik tidak ada. Ibu yang berpengetahuan cukup mempunyai pekerjaan ibu rumah tangga ada $20(52.6 \%)$ responden.

Hasil uji statistik diperoleh p value 0.742 pada derajat kemaknaan 5\% maka dapat disimpulkan tidak ada hubungan yang bermakna antara pekerjaan dengan pengetahuan ibu dalam pemberian MP ASI. 
e. Hubungan Sosial Ekonomi dengan Pengetahuan

Tabel 11. Hubungan Sosial Ekonomi Dengan Pengetahuan Ibu di Margomulyo, Seyegan, Sleman, Yogkarta 2019

\begin{tabular}{|c|c|c|c|c|c|c|c|}
\hline \multirow{2}{*}{$\begin{array}{c}\text { Sosial } \\
\text { ekonomi }\end{array}$} & \multicolumn{4}{|c|}{ Tingkat pengetahuan } & \multirow[t]{2}{*}{ Total } & \multirow[t]{2}{*}{$\%$} & \multirow[t]{2}{*}{$\mathbf{P}$} \\
\hline & Cukup & $\%$ & Baik & $\%$ & & & \\
\hline$<500.000$ & 6 & 15.8 & 1 & 2.6 & 7 & 18.4 & 0.316 \\
\hline $\begin{array}{c}50.000 .000- \\
1.000 .000\end{array}$ & 9 & 23.7 & 8 & 21.1 & 17 & 44.7 & \\
\hline$>1.000 .000$ & 9 & 23.7 & 5 & 13.2 & 14 & 36.8 & \\
\hline Total & 24 & 63.2 & 14 & 36.8 & 38 & 100 & \\
\hline
\end{tabular}

Hasil penelitian menunjukkan bahwa ibu dengan sosial ekonomi kurang dari 500000 dengan pengetahuan baik ada 1 (2.63\%) responden. Ibu dengan sosial ekonomi 500000-1000000 dan lebih dari 1000000 dengan pengetahuan cukup ada $9(23.68 \%)$ repsonden.

Hasil uji statistik diperoleh p value 0.316 pada derajat kemaknaan 5\% maka dapat disimpulkan tidak ada hubungan yang bermakna antara sosial ekonomi dengan pengetahuan ibu dalam pemberian MP ASI.

f. Hubungan Sumber Informasi Dengan Pengetahuan Ibu

Tabel 12. Hubungan Sumber Informasi Dengan Pengetahuan Ibu di Margomulyo, Seyegan, Sleman, Yogyakarta 2019

\begin{tabular}{llllllll}
\hline Sosial ekonomi & \multicolumn{3}{l}{ Tingkat pengetahuan } & & Total & $\%$ & P \\
& Cukup & $\%$ & Baik & $\%$ & & & \\
\hline$<500.000$ & 6 & 15.8 & 1 & 2.6 & 7 & 18.4 & 0.728 \\
$500.000-1.000 .000$ & 9 & 23.7 & 8 & 21.1 & 17 & 44.7 & \\
$>1.000 .000$ & 9 & 23.7 & 5 & 13.2 & 14 & 36.8 & \\
Total & 24 & 63.2 & 14 & 36.8 & 38 & 100 & \\
\hline
\end{tabular}

Hasil penelitian menunjukkan bahwa dantara 38 ibu terdapat ibu yang berpengetahuan cukup yang mendapatkan informasi melalui puskesmas sebanyak 15 orang $(39.47 \%)$.

Hasil uji statistik diperoleh p value 0.728 pada derajat kemaknaan 5\% maka dapat disimpulkan tidak ada hubungan yang bermakna antara sumber informasi dengan pengetahuan ibu dalam pemberian MP ASI.

\section{B. PEMBAHASAN}

\section{Pengetahuan Ibu tentang Pemberian MP ASI}

Pengetahuan atau kognitif merupakan domain yang sangat penting dalam membentuk tindakan seseorang. Pengetahuan merupakan hasil dari tahu dan ini tejadi setelah orang melakukan penginderaan terhadap suatu objek tertentu. Pengetahuan adalah sesuatu yang diketahui itu bisa apa saja tanpa syarat tertentu, bisa sesuatu yang didapat dengan atau tanpa metode ilmiah. Pembekalan pengetahuan ibu mengenai kapan waktu yang tepat untuk memulai pemberian 
MP ASI dan cara bagaimana menu makanan pendamping air susu ibu sangatlah penting untuk mendukung kesehatan dan tumbuh kembang bayi (Hubungan_antara_pengetahuan_rosi_kurnia_sugiharti(1).Pdf, n.d.)

Pada hasil penelitian menunjukkan bahwa ibu yang berpengetahuan baik yaitu sebanyak 12 orang (31.58\%), sedangkan ibu yang berpengetahuan cukup sebanyak 26 orang $(68.42 \%)$. Penelitian ini sejalan dengan penelitian Tristanti, 2017 bahwa hasil penelitian didapatkan pengetahuan responden tentang makanan pendamping air susu ibu bagi bayi umur 6-12 bulan adalah termasuk kategori cukup yaitu 43,3\%. Penelitian ini juga sejalan dengan penelitian Surka, dkk. 2018. Hasil yang diperoleh dalam penelitian ini yaitu sebagian besar pengetahuan ibu tentang makanan pendamping air susu ibu berada pada kategori pengetahuan cukup sebanyak 18 responden (47.4\%). Penelitian ini juga sejalan dengan penelitian Lestari, D. 2012 bahwa tingkat pengetahuan ibu tentang makanan pendamping air susu ibu pada anak usia 6-24 bulan dalam kategori cukup yaitu 29 responden (64.44\%)

Pengetahuan tentang makanan pendamping air susu ibu, sangat penting bagi calon ibu maupun ibu yang sudah mempunyai anak. Pengetahuan mempunyai pengaruh terhadap tindakan atau perilaku seseorang. Pengetahuan (knowledge) adalah kesan didalam manusia sebagai hasil penggunaan pancainderanya. Pengetahuan sangat berbeda dengan kepercayaan (beliefs), takhayul (superstition), dan penerangan-penerangan yang keliru (misinformation). Pengetahuan adalah segala apa yang diketahui berdasarkan pengalaman yang didapatkan oleh setiap manusia. Pengetahuan merupakan hasil tahu dari manusia, yang sekedar menjawab pertanyaan "what", misalnya apa air, apa manusia, apa alam, dan sebagainya. Pengetahuan merupakan respons mental seseorang dalam hubungannya objek tertentu yang disadari sebagai 'ada' atau terjadi dan objek yang disadari memang harus 'ada' sebagaimana adanya.

\section{Hubungan umur dengan pengetahuan ibu dalam pemberian MP ASI}

Umur merupakan periode terhadap pola-pola kehidupan baru dan harapanharapan baru. Semakin bertambahnya umur seseorang maka semakin banyak pula ilmu pengetahuan yang dimiliki.

Dari hasil penelitian diketahui ibu yang paling banyak berpengetahuan cukup yaitu ibu yang berusia 21-35 tahun sebanyak 16 orang (41.2\%).

Menurut Budiman dan Riyanto (2013), faktor-faktor yang mempengaruhi pengetahuan meliputi faktor internal dan eksternal. Faktor internal meliputi usia. Usia semakin bertambah usia semakin berkembang daya tangkap dan pola pikirnya sehingga pengetahuan yang diperolehnya semakin membaik.

Hasil penelitian ini tidak sejalan dengan penelitian (Khairunnisa, 2013) bahwa terdapat hubungan antara umur, jumlah pendapatan keluarga dan pengetahuan ibu dengan pemberian makanan pendamping air susu ibu pada bayi di Wilayah kerja Puskesmas Siantan Tengah pada tahun 2013.

\section{Hubungan paritas dengan pengetahuan ibu}

Hasil penelitian menunjukkan bahwa paritas ibu mutipara mempunyai pengetahuan cukup ada 19 responden (50\%). Hal ini sejalan dengan penelitian Ibrahim, dkk. 2014 bahwa tidak ada hubungan antara paritas dengan riwayat pemberian MP air susu ibu. 
Hal ini tidak sejalan dengan hasil penelitian Aprilia, et all 2020 bahwa dari hasil analisis multivariat ternyata variable yang berhubungan dengan pengetahuan adalah paritas. Hasil analisis didapatkan OR dari variable paritas adalah 14,1 artinya ibu dengan jumlah paritas 1 memiliki pengetahuan 14 kali lebih baik dibandingkan ibu dengan jumlah paritas > atau sama dengan 2 setelah dikontrol variable umur, pendidikan dan ASI eksklusif. Paritas yang paling besar pengaruhnya terhadap pengetahuan ibu. Variabel paritas atau jumlah anak dalam penelitian ini didapatkan sebagian baru memiliki 1 anak yang artinya baru pertama sebanyak 19 (54.3\%). Selain faktor usia, pendidikan ibu, kepemilikan buku KIA dan Riwayat ASI Eksklusif sesuai hasil penelitian variable paritas yang paling besar pengaruhnya terhadap pengetahuan ibu dalam pemberian MP ASI hal tersebut mungkin terjadi karena ibu dengan anak pertama lebih ingin mencari informasi dengan perkembangan teknologi yang ada saat ini seperti mencari di media sosial, mengikuti kelas-kelas yang diadakan RS, klinik, Puskesmas dan komunitas serta mereka yang sudah terbiasa dengan teknologi atau gawai. Variabel paritas adalah variable yang paling dominan atau besar pengaruhnya terhadap pengetahuan ibu tentang makanan pendamping ASI (MP ASI) sehingga diberikan informasi yang tepat sejak kehamilan terkait ASI Eksklusif dan Pemberian MP-ASI. Variabel paritas adalah variable yang paling dominan atau besar pengaruhnya terhadap pengetahuan ibu tentang makanan pendamping ASI (MP-ASI) sehingga para ibu sudah diberikan informasi yang tepat sejak kehamilan terkait ASI Eksklusif dan Pemberian MPASI dan bisa mencari informasi menggunakan teknologi atau gawai untuk bisa mengakses informasi pemberian MP-ASI yang tepat.

\section{Hubungan pendidikan dengan pengetahuan ibu dalam pemberian MP ASI}

Pendidikan menunjuk pada suatu tindakan atau pengalaman yang mempunyai pengaruh yang berhubungan dengan pertumbuhan atau perkembangan jiwa, watak, aau kemampuan fisik individu (Wahid et al., 2020). Pendidikan berarti hubungan yang diberikan oleh seseorang terhadap perkembangan orang lain menuju kearah suatu cita-cita tertentu. Jadi dapat dikatakan bahwa pendidikan itu menuntut manusia untuk berbuat dan mengisi kehidupannya untuk mencapai keselamatan dan kebahagiaan.

Pendidikan diperlukan untuk mendapatkan informasi misalnya hal-hal yang menunjang kesehatan, sehingga dapat meningkatkan kualitas hidup seseorang. Selain itu pendidikan merupakan faktor utama yang berperan dalam menambah informasi dan pengetahuan seseorang. Oleh karena itu tingkat pendidikan sering dijadikan sebagai bahan kualifikasi atau prasyarat serta dijadikan sebagai pandangan dalam membedakan tingkat pengetahuan seseorang.

Pengetahuan itu sendiri dipengaruhi oleh faktor pendidikan formal. pengetahuan sangat erat hubungannya dengan pendidikan, dimana diharapkan bahwa dengan pendidikan yang tinggi maka orang tersebut akan semakin luas pula pengetahuannya. Akan tetapi perlu ditekankan, bukan berarti seseorang yang berpendidikan rendah mutlak berpengetahuan rendah pula. Hal ini mengingat bahwa peningkatan pengetahuan tidak mutlak diperoleh dari pendidikan formal saja, akan tetapi dapat diperoleh melalui pendidikan non formal. Pengetahuan seseorang tentang suatu objek mengandung dua aspek yaitu aspek positif dan aspek negatif. Kedua aspek ini yang akan menentukan sikap 
seseorang, semakin banyak aspek positif dan objek yang diketahui, maka akan menimbulkan sikap semakin positif terhadap objek tertentu. Pendidikan berarti bimbingan yang diberikan seseorang kepada orang lain terhadap suatu hal agar mereka dapat memahami. Tidak dapat dipungkiri bahwa makin tinggi pendidikan seseorang semakin mudah pula mereka menerima informasi, dan pada akhirnya makin banyak pula pengetahuan yang dimilikinya. Sebaliknya, jika seseorang tingkat pendidikannya rendah, akan menghambat perkembangan sikap seseorang terhadap penerimaan, informasi dan nilai-nilai yang baru diperkenalkan.

Dari hasil univariat ditemukan bahwa responden yang berpendidikan SMA $57.89 \%$. Hasil penelitian dilihat dari segi pendidikan ini sejalan dengan penelitian (Rahayu et al., 2018) bahwa dilihat dari segi pendidikan yang kebanyakan adalah baik (SMA) dapat dikatakan bahwa tidak ada hubungan dengan pengetahuan ibu.

Hasil penelitian ini tidak sejalan dengan penelitian Ibrahim, dkk. 2014. Hasil penelitian terdapat hubungan yang bermakna antara pendidikan, pekerjaan, pengetahuan, sikap dengan riwayat pemberian makanan pendamping air susu ibu.

\section{Hubungan pekerjaan dengan pengetahuan ibu dalam Pemberian makanan pendamping air susu ibu}

Tingkat pengetahuan juga dipengaruhi oleh pekerjaan, mereka lebih banyak mengurusi pekerjaannya artinya mereka sering bersosialisasi dengan lingkungan, hal ini akan berpengaruh terhadap perilaku seseorang dimana perilaku yang didasari pengetahuan akan lebih langgeng dibandingkan perilaku yang tidak didasari pengetahuan. Pekerjaan sangat berpengaruh terhadap sosial ekonomi seseorang. Sosial ekonomi disini maksudnya adalah tingkat kemampuan seseorang untuk memenuhi kebutuhan hidupnya. Semakin tinggi tingkat sosial ekonomi memungkinkan seseorang untuk mempunyai fasilitasfasilitas yang mendukung seseorang mendapatkan informasi dan pengalaman yang lebih banyak. Lingkungan pekerjaan dapat menjadikan seseorang memperoleh pengalaman dan pengetahuan baik secara langsung maupun secara tidak langsung (Kusmiyati et al., 2014).

Pada hasil penelitian didapatkan sebanyak 20 orang $(52.6 \%)$ ibu tidak bekerja mempunyai pengetahuan cukup dan 9 orang $(47.4 \%)$ bekerja. Jenis pekerjaan seperti pegawai swasta, buruh, karyawan. Penelitian ini sejalan dengan penelitian Kusmiyati dkk. 2014 menunjukkan tidak terdapat hubungan antara pekerjaan dengan pemberian makanan pendamping air susu ibu p-value 0.052 .

\section{Hubungan sosial ekonomi dengan pengetahuan ibu tentang pemberian makanan pendamping air susu ibu}

Tingkat ekonomi keluarga dapat dinilai dari beberapa hal. Menurut tingkat ekonomi keluarga responden dibagi menjadi tiga kategori yaitu rendah, sedang, tinggi. Responden yang paling kurang mengenai pengetahuan dalam pemberian makanan pendamping air susu ibu. 
Hasil penelitian bahwa tidak ada bubungan yang signifikan antara social ekonomi dengan pengetahuan ibu tentang pemberian MP ASI. Penelitian ini sejalan dengan penelitian (Sitepu et al., 2012) bahwa tidak terdapat hubungan antara pendapatan, pekerjaan, dan jumlah anggota keluarga dengan usia pertama pemberian MP-ASI pada bayi usia 6-12 bulan.

\section{Hubungan sumber informasi dengan pengetahuan ibu dalam pemberian makanan pendamping air susu ibu}

Sumber informasi adalah segala sesuatu yang menjadi perantara dalam menyampaikan informasi. Media informasi untuk komunikasi massa terdiri dari media cetak yaitu surat kabar, majalah, buku. Media elektronik yaitu radio, TV, film dan sebagainya. Hasil analisa bivariat menunjukkan bahwa tidak ada hubungan yang bermakna antara sumber informasi dengan pengetahuan ibu dalam memberikan MP ASI. Faktor-faktor yang memengaruhi pengetahuan adalah informasi. Kemudahan untuk memperoleh suatu informasi dapat membantu mempercepat seseorang untuk memperoleh pengetahuan yang baru (Desiyanti, 2016).

\section{SIMPULAN}

Berdasarkan hasil penelitian yang telah dilakukan, maka dapat disimpulkan sebagai berikut: Gambaran pengetahuan ibu dalam pemberian makanan pendamping air susu ibu yaitu ibu yang berpengetahuan cukup lebih banyak dibandingkan ibu yang berpengetahuan baik. Responden paling banyak berumur 21-35 tahun. Responden paling banyak ibu yang berpendidikan menengah. Gambaran pekerjaan ibu, ibu yang tidak bekerja lebih banyak dibandingkan ibu bekerja. Responden paling banyak bersosial ekonomi Rp 500.000,00-Rp 1.000.000,00. Responden paling banyak mendapatkan informasi dari Puskesmas. Faktor yang mempengaruhi pengetahuan antara lain pendidikan, informasi atau media massa, sosial, budaya dan ekonomi, lingkungan, pengalaman.

\section{DAFTAR PUSTAKA}

Aprillia, Y. T., Nugraha, S., \& Mawarni, E. S. (2019). Efektifitas Kelas Edukasi Makanan Pendamping Asi ( Mp-Asi ) Dalam Peningkatan Pengetahuan Ibu Bayi. Jurnal Bidang Ilmu Kesehatan, 9(2), 126-133.

Apriyanti Widyasari. (2018). Status Gizi Anak. In Mkmi (Vol. 1, Issue 2).

Autoridad Nacional Del Servicio Civil. (2021). 済無no Title No Title No Title. In Angewandte Chemie International Edition, 6(11), 951-952.

Bayar, S. (2018). No 主観的健康感を中心とした在宅高齢者における 健康関 連指標に関する共分散構造分析itle. 9, 36-39.

Birth, J. L. (2020). Jurnal Life Birth. 4, 134-142.

Da Cunha, A. J. L. A., Leite, Á. J. M., \& De Almeida, I. S. (2015). Atuação Do Pediatra Nos Primeiros Mil Dias Da Criança: A Busca Pela Nutrição E 
Desenvolvimento Saudáveis. Jornal De Pediatria, 91(6), S44-S51. Https://Doi.Org/10.1016/J.Jped.2015.07.002

Desiyanti. (2016). Pengetahuan Dan Sikap Ibu Tentang Pemberian Makanan Pendamping Asi (Mp-Asi) Pada Bayi Usia 6-12 Bulan Di Puskesmas Poasia Kota Kendari. Karya Tulis Ilmiah Poltekkes Kemenkes Kendari.

Hubungan_Antara_Pengetahuan_Rosi_Kurnia_Sugiharti(1).Pdf. (N.D.).

Ibi/Ima, I. M. A., \& Imap, I. M. A. Of The P. (2018). Midwives Leading The Way With Quality Care. International Midwifery Scientifc Conference, 1-499.

Khairunnisa, W. S. (2013). Hubungan Karakteristik, Pengetahuan Dan Sikap Ibu Dengan Pemberian Mp-Asi Pada Bayi Di Wilayah Kerja Puskesmas Siantan Tengah. Jurnal Mahasiswa Pspd Fk Universitas Tanjungpura.

Kusmiyati, K., Adam, S., \& Pakaya, S. (2014). Hubungan Pengetahuan, Pendidikan Dan Pekerjaan Ibu Dengan Pemberian Makanan Pendamping Asi ( Mp - Asi ) Pada Bayi Di Puskesmas Bahu Kecamatan Malalayang Kota Manado. Jurnal Ilmiah Bidan, 2(2), 91606.

Mattos, G. E. (2011). No 主観的健康感を中心とした在宅高齢者における 健 康関連指標に関する共分散構造分析title. July.

Nengsih, Y., Kubillawati, S., \& Daulay, N. A. (2020). Pengaruh Penyuluhan Terhadap Pengetahuan Ibu Dalam Membuat Mp-Asi Di Posyandu Rw 001 Desa Mampir Puskesmas Gandoang Cileungsi Tahun 2019. Jurnal Ilmiah Kesehatan Dan Kebidanan, 9(2).

Rahayu, A., Rahman, F., \& Marlinae, L. (2018). Buku Ajar 1000 Hpk. In Buku Ajar Gizi $1000 \quad$ Hari Pertama Kehidupan. Https://Www.Google.Com/Url?Sa=T\&Source=Web\&Rct=J\&Url=Http://Kes mas.Ulm.Ac.Id/Id/Wp-Content/Uploads/2019/02/Buku-Ajar-1000-HariPertamaKehidupan.Pdf \&Ved=2ahukewiliocrytvyahuut30khx6vdqmqfnoecbo qaq\&Usg=Aovvaw3t3vo8fmqsbaq4fazxjrqd

Siolimbona, A., Ridwan, E. S., \& Hati, F. S. (2016). Gambaran Tingkat Pengetahuan Ibu Tentang Makanan Pendamping Asi (Mp-Asi) Anak Umur 624 Bulan Di Dusun Pedes, Bantul, Yogyakarta. Jurnal Gizi Dan Dietetik Indonesia (Indonesian Journal Of Nutrition And Dietetics), 4(1), 57. Https://Doi.Org/10.21927/Ijnd.2016.4(1).57-62

Sitepu, C. M., Punuh, M. I., Kawengian, S. E. S., Kedokteran, F., \& Sam, U. (2012). Hubungan Antara Sosial Ekonomi Dengan Usia Pertama Pemberian Makanan Pendamping Asi (Mp-Asi) Pada Usia 6-12 Bulan Di Puskesmas Tuminting Kota Menado. 1-8.

Tria, G., Nurhamidah, N., \& Amir, H. (2018). Potensi Ekstrak Metabolit Sekunder Eugenia Uniflora L. Sebagai Bahan Pengawet Tahu. Alotrop, 2(1), 39-45. 
Https://Doi.Org/10.33369/Atp.V2i1.4630

Wahid, A., Hannan, M., Ratna, S., Dewi, S., \& Hidayah, R. H. (2020). FaktorFaktor Yang Berhubungan Dengan Kejadian Stunting Pada Balita. Journal Of Health Science. V(Ii), 92-102.

Wandini, R., Rilyani, \& Resti, E. (2021). Pemberian Makanan Pendamping Asi (Mp-Asi) Berhubungan Dengan Kejadian Stunting Pada Balita. Jurnal Kebidanan Malahayati, 7(2), 274-278.

Widyaningtyas, P. A. (2015). Pendamping Asi Pada Ibu Dengan Balita Gizi Kurang Usia 6-24 Bulan Sebelum Dan Sesudah. 